\title{
Serum and ascitic fluid hepcidin in HCV positive liver cirrhosis with and without HCC
}

\author{
Ehab Abd El Atti ${ }^{1,}$, Alaa Dawood ${ }^{1}$, Abdallah Said Essa ${ }^{2}$, Bassam Mohamed Masoud $^{2}$, \\ Enas Said Essa ${ }^{3}$, Yasser El-Ghobashy ${ }^{4}$, Ashraf Anas Zytoon ${ }^{5}$
}

${ }^{1}$ Internal Medicine Department, Faculty of Medicine, Menoufiya University, Egypt

${ }^{2}$ Tropical Medicine Department, Faculty of Medicine, Menoufiya University, Egypt

${ }^{3}$ Clinical Pathology Department, Faculty of Medicine, Menoufiya University, Egypt

${ }^{4}$ Biochemistry Department, Faculty of Medicine, Menoufiya University, Egypt

${ }^{5}$ Radiology Department, Faculty of Medicine, Menoufiya University, Egypt

\author{
Email address: \\ ehab_abdelatty@hotmail.com (E. A. El Atti)
}

\section{To cite this article:}

Ehab Abd El Atti, Alaa Dawood, Abdallah Said Essa, Bassam Mohamed Masoud, Enas Said Essa, Yasser El-Ghobashy, Ashraf Anas Zytoon. Serum and Ascitic Fluid Hepcidin in HCV Positive Liver Cirrhosis with and without HCC. European Journal of Preventive Medicine. Vol. 1, No. 3, 2013, pp. 63-69. doi: 10.11648/j.ejpm.20130103.13

\begin{abstract}
Background \& Aim: Chronic HCV infection suppresses hepatic hepcidin expression which may enhance iron toxicity and lead to disease progression and HCC development. The aim of the study is to investigate the role of hepcidin in $\mathrm{HCV}+\mathrm{ve}$ liver cirrhosis patients in relation to disease progression and HCC development. Patients and methods: The study population consists of: $20 \mathrm{HCV}+\mathrm{ve}$ patients without $\mathrm{HCC}$ ( $\mathrm{HCV}$ patients), $20 \mathrm{HCV}+\mathrm{ve}$ patients with $\mathrm{HCC}$ (HCV-HCC patients) and 10 controls. In addition to comprehensive clinical examination, they were subjected to laboratory check-up for albumin, bilirubin, PT \%, ferritin, AFP and hepcidin. Ascitic fluid hepcidin was done for all patients. Results: There was a significant difference among HCV and HCV-HCC patients and controls with regard serum ferritin and hepcidin $(P=0.001$ \& 0.0001 respectively). Serum hepcidin of HCV and HCV-HCC patients were significantly lower than controls $(P=$ $0.0001)$. Serum and ascitic fluid hepcidin of HCV-HCC patients was significantly lower than HCV patients $(P=0.01 \&$ 0.02 respectively). Serum ferritin was significantly higher in HCV and HCV-HCC patients than controls $(P=0.001)$. Serum ferritin of HCV-HCC patients was significantly higher than HCV patients $(P=0.02)$. Ascitic fluid hepcidin was negatively correlated with Child-Pugh score in HCV $(r=-0.55 \& P=0.01)$ and HCV-HCC patients $(r=-0.53 \& P=0.02)$. Ascitic fluid hepcidin was negatively correlated with bilirubin in HCV $(r=-0.43 \& P=0.04)$ and HCV-HCC patients $(r=-$ $0.47 \& P=0.04)$. Ascitic fluid hepcidin was positively correlated with serum albumin in $\mathrm{HCV}(r=+0.44 \& P=0.04)$ but there was no correlation in HCV-HCC patients $(r=-0.1 \& P=0.7)$. Conclusion: Low levels of hepcidin may be involved in the pathophysiologic mechanism of iron overload in patients with chronic HCV with and without HCC. Moreover, there is a positive relationship between hepcidin levels and synthetic liver function suggesting that uniform suppression of hepcidin may be linked to disease progression and HCC development. Further analysis is still required to evaluate its usefulness as a marker for early detection of HCC by serial measurement of hepcidin in blood and ascitic fluid.
\end{abstract}

Keywords: Hepcidin, HCC, HCV, Ferritin

\section{Introduction}

Infection with hepatitis $\mathrm{C}$ virus (HCV) is a common problem worldwide, affecting millions of people across all populations. Most acutely infected patients develop chronic hepatitis and become a potential source of virus transmission, and as many as 1 in 5 will develop cirrhosis and its complications such as hepatocellular carcinoma (HCC) ${ }^{(1)}$. HCC is the commonest primary cancer of the liver. Incidence is increasing and HCC has risen to become the 5th commonest malignancy worldwide and the third leading cause of cancer related death ${ }^{(2)}$. Egypt has the highest prevalence of $\mathrm{HCV}$ worldwide and has rising rates of $\mathrm{HCC}^{(3,4)}$.

Hepcidin is a cysteine-rich circulating bioactive peptide that is predominantly secreted from the liver and excreted in the urine ${ }^{(5)}$. Hepcidin is a novel peptide due to its dual role as an 'iron-hormone' and 'antimicrobial peptide. 
Hepcidin is likely to play a role in innate immunity ${ }^{(6)}$.

Hepcidin controls plasma iron concentration and tissue distribution of iron. It inhibits intestinal iron absorption by enterocytes in the duodenum through its binding to ferroportin and inducing its internalization and degradation (7). It also causes a release of iron by macrophages and hepatocytes ${ }^{(8)}$. These mechanisms result in a decrease of serum iron concentration and increased intracellular iron content $^{(9)}$.

Hepcidin was shown to be present in urine and serum. However, its expression by various organs such as salivary glands, tonsils, trachea, lung and prostate has also been reported ${ }^{(10)}$. Hepcidin is in bile and may act along with $\alpha$ defensins against gut microflora (11). Arnold et al. (12) demonstrate the presence of hepcidin in pleural and ascitic fluid with unknown biological activity. Shike et al. (13) showed that in white bass liver, infection with the fish pathogen Streptococcus iniae increased hepcidin mRNA expression 4500-fold.

Synthesis of hepcidin is homeostatically increased by iron loading and decreased by anemia and hypoxia ${ }^{(14)}$. Hepcidin regulates serum iron levels during inflammation, infection and possibly also in cancer. Under these conditions iron is shifted from circulation into cellular stores in hepatocytes and macrophages, making it less available for invading microorganisms and tumor cells ${ }^{(15)}$.

At the opposite side of the spectrum, hepcidin deficiency appears to be the ultimate cause of most forms of hemochromatosis, either due to mutations in the hepcidin gene itself or due to mutations in the regulators of hepcidin synthesis $(14,16)$.

$\mathrm{HCV}$ infection is associated with alterations in body iron homeostasis through a poorly understood mechanism. Chronic HCV infection suppresses hepatic hepcidin expression. The impairment of hepatic hepcidin production occurring with chronic $\mathrm{HCV}$ infection may enhance iron toxicity and lead to disease progression ${ }^{(17)}$.

Although, hepcidin mRNA expression was detected in surgical specimens from patients with colorectal cancer ${ }^{(18)}$, and renal cell carcinoma ${ }^{(19)}$, few studies investigated the relation of hepcidin and $\mathrm{HCC}$ development.

The aim of our study is to investigate the role of serum and ascitic fluid hepcidin in HCV positive liver cirrhosis patients in relation to disease progression and complications like HCC.

\section{Patients and Methods}

The study included $40 \mathrm{HCV}$ positive liver cirrhosis patients (previously diagnosed by PCR for HCV-RNA) selected from Internal Medicine and Tropical Medicine Departments in Menofiya University Hospital. The patients were divided into: $20 \mathrm{HCV}$ positive patients without HCC (HCV patients) and $20 \mathrm{HCV}$ positive patients with $\mathrm{HCC}$ (HCV-HCC patients). They are 37 males and 3 females ranged between $38-72$ years old. In addition, ten healthy individuals are selected as controls.
Patients were diagnosed clinically, by abdominal ultrasonography (liver and spleen status and degree of ascites) and by assessing viral markers (HBsAg, HCV Ab and quantitative PCR for $\mathrm{HCV}-\mathrm{RNA}$ ). $\mathrm{HCC}$ is further confirmed by triphasic CT of the liver and AFP. All HCVHCC patients were newly diagnosed cases and did not receive prior chemotherapy. Exclusion criteria included HBsAg positive patients, patients with concomitant causes of chronic liver diseases and history of alcohol consumption. Patients with hemochromatosis or with previous history of any malignancy are excluded from the study as those are expected to exhibit abnormal hepcidin regulation. All patients and controls gave their written informed consent before participating in the study. The study was approved by our Ethical Committee of Faculty of Medicine.

For all patients and controls, full history taking and complete clinical examination were done. A blood sample was withdrawn by sterile venipuncture and divided into three parts: EDTA was added to the first sample which was used for complete blood count (using the cell counter, Pentra 80, France). A second sample with sodium citrate was used to estimate prothrombin activity. The third sample was put in a plain vacutainer tube which was left to clot at $37^{\circ} \mathrm{C}$ then centrifuged and serum was separated. Serum was used to estimate AST, ALT, albumin, bilirubin, blood urea and serum creatinine (Beckman Synchron CX5 Clinical System, Minnesota, USA). Serum AFP measurements was done on AxSYM (AxSYM, Abbott Diagnostics, USA). Serum ferritin was measured using Ferritin AccuBind ELISA kit (Monobind Inc. Düsseldorf, Germany). A double-antibody sandwich enzyme-linked immunosorbent assay (ELISA) was used to assay the level of Human Hepcidin (Hepc) in probably diluted serum samples (Glory Science Co., Ltd, USA) Hepcidin in the sample was added to monoclonal antibody Enzyme well which is pre-coated with Human Hepcidin monoclonal antibody, followed by incubation; then, Hepcidin antibodies labeled with biotin, and combined with Streptavidin-HRP to form immune complex was added; then carrying out incubation and washing again to remove the uncombined enzyme. Then Chromogen Solution A, B was added; the color of the liquid changed into the blue and at the effect of acid, the color finally became yellow. The chroma of color and the concentration of the Human Substance Hepcidin of sample were positively correlated. Ascitic fluid hepcidin was done for all patients.

\subsection{Statistical Analysis}

Results are presented as mean \pm standard deviation (SD) unless otherwise stated. For comparison of two means, the unpaired $t$ test and non-parametric Mann-Whitney test were used. The ANOVA test with post hoc was used to compare among $\mathrm{HCV}$ positive patients with and without $\mathrm{HCC}$ and controls. Fisher Exact analysis was also applied to compare proportions between groups. Pearson coefficient was used to study correlations between different parameters. A $P$ - 
value of $\leq 0.05$ was considered statistically significant. All statistical analyses were performed using the Statistical Package for Social Science (SPSS) software version 10.

\section{Results}

Comparison among HCV patients, HCV-HCC patients and controls (Table 1) showed that there was a significant difference with regard serum ferritin and serum hepcidin levels $(P=0.0001$ and 0.001 respectively). Serum hepcidin level of HCV and HCV-HCC patients were significantly lower than controls $(P=0.0001$ for both). Serum hepcidin level of HCV-HCC patients was significantly lower than HCV patients $(P=0.01)$. Serum ferritin level was significantly higher in $\mathrm{HCV}$ and $\mathrm{HCV}-\mathrm{HCC}$ patients than controls $(P=0.001$ for both). Serum ferritin level of HCVHCC patients was significantly higher than $\mathrm{HCV}$ patients $(P=0.02)$.

Table 2 shows a comparison between HCV and HCVHCC patients. Ascitic fluid hepcidin was significantly lower in HCV-HCC than in HCV patients $(P=0.02)$. Blood urea of HCV-HCC patients was significantly higher than HCV patients $(P=0.003)$. HCV-HCC patients had significantly lower serum albumin than $\mathrm{HCV}$ patients $(P=$ 0.0001). HCV-HCC patients had significantly higher AFP level than HCV patients $(P=0.0001)$.

The severity of the liver disease was graded according to Child-Pugh's criteria. Three patients $(15 \%)$ belonged to Child's class B in HCV and HCV-HCC patients. Seventeen patients $(85 \%)$ belonged to Child's class $\mathrm{C}$ in $\mathrm{HCV}$ and HCV-HCC patients.

Table 3 shows correlation between ascitic fluid hepcidin and different parameters in HCV and HCV-HCC patients. Ascitic fluid hepcidin was negatively correlated with ChildPugh score in HCV patients $(r=-0.55, P=0.01)$ and HCVHCC patients $(r=-0.53, P=0.02)$. Ascitic fluid hepcidin was negatively correlated with total bilirubin level in $\mathrm{HCV}$ patients $(r=-0.43, P=0.04)$ and HCV-HCC patients $(r=-$ $0.47, P=0.04)$. Ascitic fluid hepcidin was positively correlated with serum albumin level in HCV patients $(r=$ $+0.44, P=0.04)$ but there was no correlation in HCV-HCC patients $(r=-0.1, P=0.7)$.

Table 1. Comparison among HCV patients, HCV-HCC patients and controls (data expressed as mean $\pm S D$ )

\begin{tabular}{|c|c|c|c|c|c|}
\hline & $\begin{array}{l}\text { HCV patients } \\
(\mathrm{n}=20)\end{array}$ & $\begin{array}{l}\text { HCV-HCC } \\
\text { patients }(n=20)\end{array}$ & $\begin{array}{l}\text { Controls } \\
(n=10)\end{array}$ & $P$-value & LSD \\
\hline Age (years) & $57.1 \pm 7.9$ & $56.1 \pm 8.2$ & $55 \pm 7.3$ & 0.8 & \\
\hline Gender (male \%) & $90 \%(n=18)$ & $95 \%(n=19)$ & $80 \%(\mathrm{n}=8)$ & NS & \\
\hline Serum hepcidin (pg/ml) & $16175 \pm 892.6$ & $15250 \pm 723.7$ & $18100 \pm 516.4$ & $0.0001 *$ & $\begin{array}{l}* \mathrm{HCV} \text { vs Controls *HCV-HCC vs Controls } \\
* \mathrm{HCV} \text { vs HCV-HCC } \\
* \mathrm{HCV} \text { vs Controls }\end{array}$ \\
\hline Serum ferritin $(\mathrm{mg} / \mathrm{dl})$ & $244.8 \pm 92.3$ & $299.2 \pm 83.9$ & $145 \pm 41.9$ & $0.001 *$ & $\begin{array}{l}* \mathrm{HCV}-\mathrm{HCC} \text { vs Controls } \\
* \mathrm{HCV} \text { vs HCV-HCC }\end{array}$ \\
\hline
\end{tabular}

$\mathrm{n}=$ number, $*$ =significant, $\mathrm{PT} \%=$ Prothrombin activity, WBCs $=$ White blood count, $\mathrm{AFP}=\mathrm{Alpha}$ fetoprotein, $\mathrm{LSD}=\mathrm{Least}$ significant difference

Table 2. Comparison between HCV and HCV-HCC patients (data expressed as mean $\pm S D$ )

\begin{tabular}{|c|c|c|c|}
\hline & $\begin{array}{l}\text { HCV patients } \\
(\mathbf{n}=\mathbf{2 0})\end{array}$ & $\begin{array}{l}\text { HCV-HCC patients } \\
(n=20)\end{array}$ & $P$-value \\
\hline Hemoglobin (gm/dl) & $8.7 \pm 1$ & $9.4 \pm 1.6$ & 0.1 \\
\hline WBCs $\left(\times 10^{3} / \mathrm{mm}^{3}\right)$ & $8.6 \pm 4.6$ & $10.1 \pm 6$ & 0.7 \\
\hline Platelet count $\left(\times 10^{3} / \mathrm{mm}^{3}\right)$ & $94.1 \pm 42.2$ & $84.8 \pm 40.9$ & 0.8 \\
\hline Blood urea (mg/ dl) & $41.8 \pm 23.6$ & $122.4 \pm 80.5$ & $0.003 *$ \\
\hline Serum creatinine $(\mathrm{mg} / \mathrm{dl})$ & $1.7 \pm 0.5$ & $1.7 \pm 1$ & 0.9 \\
\hline AST (U/L) & $55.6 \pm 21.4$ & $81.6 \pm 63.9$ & 0.3 \\
\hline $\operatorname{ALT}(\mathrm{U} / \mathrm{L})$ & $63.6 \pm 29.8$ & $58.8 \pm 45.7$ & 0.2 \\
\hline Serum albumin(gm/dl) & $2.68 \pm 0.27$ & $2.15 \pm 0.41$ & $0.0001 *$ \\
\hline Total bilirubin(mg/dl) & $3.6 \pm 1.5$ & $3.9 \pm 2.6$ & 0.6 \\
\hline PT $(\%)$ & $46.8 \pm 9.9$ & $43.9 \pm 11.8$ & 0.4 \\
\hline Child-Pugh score (points) & $11.6 \pm 1.7$ & $11.4 \pm 1.7$ & 0.8 \\
\hline $\operatorname{AFP}(\mathrm{ng} / \mathrm{ml})$ & $8.8 \pm 5.4$ & $629.5 \pm 104.6$ & $0.0001 *$ \\
\hline Ascitic hepcidin (pg/ml) & $24677 \pm 3451$ & $22713 \pm 2983$ & $0.02 *$ \\
\hline
\end{tabular}


Table 3. Correlation between serum and ascitic fluid hepcidin and different parameters in HCV and HCV-HCC patients.

\begin{tabular}{|c|c|c|c|c|c|c|c|c|}
\hline & \multicolumn{4}{|c|}{ Serum hepcidin } & \multicolumn{4}{|c|}{ Ascitic fluid hepcidin } \\
\hline & \multicolumn{2}{|c|}{$\begin{array}{c}\text { HCV patients } \\
\quad(\mathbf{n}=20)\end{array}$} & \multicolumn{2}{|c|}{$\begin{array}{c}\text { HCV-HCC patients } \\
(n=20)\end{array}$} & \multicolumn{2}{|c|}{$\begin{array}{l}\text { HCV patients } \\
(\mathbf{n}=20)\end{array}$} & \multicolumn{2}{|c|}{$\begin{array}{l}\text { HCV-HCC patients } \\
(\mathrm{n}=20)\end{array}$} \\
\hline & $r$ & $P$-value & $r$ & $P$-value & $r$ & $P$-value & $r$ & $P$-value \\
\hline Age (years) & +0.07 & 0.8 & -0.28 & 0.3 & -0.08 & 0.7 & -0.26 & 0.3 \\
\hline Hemoglobin (gm/dl) & -0.2 & 0.3 & +0.09 & 0.7 & -0.11 & 0.7 & -0.24 & 0.3 \\
\hline WBCs $\left(\times 10^{3} / \mathrm{mm}^{3}\right)$ & -0.2 & 0.3 & -0.27 & 0.3 & -0.2 & 0.3 & +0.2 & 0.3 \\
\hline Platelet count $\left(\times 10^{3} / \mathrm{mm}^{3}\right)$ & -0.2 & 0.3 & -0.26 & 0.3 & -0.2 & 0.3 & +0.07 & 0.8 \\
\hline Blood urea (mg/ dl) & +0.3 & 0.2 & +0.15 & 0.5 & -0.006 & 0.9 & -0.009 & 0.9 \\
\hline Serum creatinine (mg/dl) & +0.14 & 0.6 & -0.27 & 0.3 & -0.14 & 0.5 & +0.14 & 0.6 \\
\hline AST (U/L) & +0.2 & 0.3 & +0.14 & 0.6 & +0.2 & 0.3 & +0.11 & 0.7 \\
\hline $\operatorname{ALT}(\mathrm{U} / \mathrm{L})$ & +0.2 & 0.3 & +0.2 & 0.4 & -0.2 & 0.3 & -0.15 & 0.6 \\
\hline Serum albumin (gm/dl) & -0.01 & 0.9 & -0.04 & 0.9 & $+0.44^{*}$ & $0.04 *$ & -0.1 & 0.7 \\
\hline Total bilirubin(mg/dl) & -0.2 & 0.3 & -0.09 & 0.9 & -0.43 & $0.04 *$ & -0.47 & $0.04 *$ \\
\hline PT (\%) & -0.2 & 0.3 & -0.19 & 0.3 & -0.03 & 0.8 & +0.04 & 0.9 \\
\hline Child-Pugh score (points) & +0.09 & 0.7 & +0.2 & 0.4 & -0.55 & $0.01 *$ & -0.53 & $0.02 *$ \\
\hline $\operatorname{AFP}(\mathrm{ng} / \mathrm{ml})$ & -0.05 & 0.8 & +0.04 & 0.9 & -0.14 & 0.5 & +0.13 & 0.6 \\
\hline Serum ferritin (ng/ml) & +0.3 & 0.2 & +0.17 & 0.5 & +0.03 & 0.9 & -0.16 & 0.6 \\
\hline
\end{tabular}

$\mathrm{n}=$ number, $\mathrm{PT} \%=$ Prothrombin activity, $\mathrm{WBCs}=$ White blood count, $\mathrm{AFP}=\mathrm{Alpha}$ fetoprotein, $\mathrm{AST}=$ Aspartate transaminase, $\mathrm{ALT}=\mathrm{Alanine}$ transaminase,

\section{Discussion}

Chronic hepatitis due to HCV infection is a leading cause of liver-related mortality all over the world, due to progression to cirrhosis and HCC. A high prevalence of iron overload has been shown in patients with chronic HCV infection characterized by different genetic backgrounds and exposure to environmental factors, suggesting that several mechanisms are involved, including inflammation, alteration of iron sensing, and deregulation of hepcidin release by hepatocytes ${ }^{(17,20)}$. Elevated iron stores have been reported to affect the outcome of antiviral therapy, and to promote fibrogenesis and the risk of $\mathrm{HCC}^{(20)}$.

Hepcidin, as an antimicrobial peptide, was first described as a liver expressed antimicrobial peptide $1^{(21)}$. Hepcidin is synthesized as preprohepcidin and undergoes posttranslational processing before release into circulation in an active form. The peptide hepcidin is proposed to be the key mediator of iron metabolism and systemic distribution. Therefore, hepcidin is considered as a negative regulator of iron release into the system by duodenal enterocytes and reticuloendothelial macrophages (22). Hepcidin is synthesized by hepatocytes in response to both iron overload and inflammatory stimuli, an effect believed to be dependent on cytokine production ${ }^{(5,21)}$. Hepcidin exerts its regulatory effect by preventing the efflux of intracellular iron from intestinal enterocytes as well as hepatocytes, macrophages and placental cells (6). Furthermore, hepcidin expression in the liver was negatively correlated with the total iron stores ${ }^{(17)}$. Iron accumulation in the liver, where hepcidin is exclusively synthesized, is common in patients with chronic liver diseases, especially in patients with chronic hepatitis $\mathrm{C}$ virus $(\mathrm{CHC})$ infection ${ }^{(23,24)}$. Excess iron deposition in the liver is known to be hepatotoxic and may exacerbate liver injury in patients with chronic hepatitis $\mathrm{C}^{(25)}$.

In the present study, Serum hepcidin level of HCV positive patients was significantly lower than healthy controls $(\mathrm{P}=0.0001)$. The results are in agreement with elegant studies in animal and cellular models that suggest a direct effect of HCV on liver hepcidin expression. Nishina et al. (26) studied transgenic mice expressing HCV polyprotein, which showed mild progressive hepatic iron accumulation. These mice had reduced hepcidin messenger RNA (mRNA) expression, which was attributed to HCV protein-induced reactive oxygen species (ROS), with consequent upregulation of an inhibitor of the binding of the transcription factor CCAAT/enhancer-binding protein $\alpha$ to the hepcidin promoter. Previously, Fujita et al. (27) reported that expression of hepcidin in patients with chronic hepatitis $\mathrm{C}$ was relatively lower than hepcidin expression in HBV positive patients and noninfected patients. Moreover, Girelli et al. ${ }^{(28)}$ demonstrated that hepcidin concentration was significantly lower in $\mathrm{CHC}$ patients than those of matched controls. Hepcidin downregulation is likely to contribute to liver iron accumulation in this condition. According to the hypothesis of a direct suppressive effect of HCV on liver hepcidin expression, one could anticipate an inverse relationship between viral loading and circulating hepcidin levels. Recently, Liu et al. ${ }^{(29)}$ further examined the anti$\mathrm{HCV}$ activity of hepcidin by gene over-expression and 
knockdown. The data clearly show that over-expression of hepcidin reduced $\mathrm{HCV}$ expression, while knockdown of hepcidin induced viral RNA expression. These results indicate that hepcidin might have a broad anti-HCV activity, at least for genotype 1 and genotype 2 . The inhibitory effect appears to occur at the viral replication level. Taken together, these results suggest that both exogenous addition of hepcidin peptide and over-expression of hepcidin could attenuate HCV replication in cell models ${ }^{(29)}$.

It is possible to develop a therapy using hepcidin. Besides its antiviral effect, the potential advantage of hepcidin therapy for $\mathrm{HCV}$ patients is restoration of iron homeostasis. It will be interesting to investigate the therapeutic efficacy of both antiviral activity and iron metabolism in small animal models or possible clinical studies. However, well-designed clinical studies addressing safety and longterm efficacy are needed in order to clarify the risks and benefits of hepcidin-targeted treatment.

On the other hand, Aoki et al. ${ }^{(30)}$ reported that hepatic hepcidin expression is increased in response to iron overload in patients with chronic hepatitis $\mathrm{C}$.

In anemia of chronic diseases, hepcidin mRNA expression is influenced by acute-phase reactant cytokines as IL- ${ }^{(31)}$, while HCV infection is a cell-mediated immune response that is characterized by a $\mathrm{T}$ helper-1 immune response with secretion of IL-2, IL-4, IL-10, tumor necrosis factor-a, and interferon- ${ }^{\left({ }^{(32}\right)}$. Thus hepcidin expression may be less influenced by $\mathrm{T}$ helper-1 cytokines in chronic HCV infection.

We examined the relationship between parameters reflecting hepatic synthetic function and hepcidin level in blood and ascitic fluid. Serum albumin level was positively correlated with ascitic fluid hepcidin levels in HCV positive patients without $\mathrm{HCC}(r=+0.46, P=0.04)$. Serum bilirubin was negatively correlated with ascitic fluid hepcidin in HCV positive patients with $(r=-0.47, P=0.04)$ and without HCC $(r=-0.43, P=0.04)$. Further study is necessary to determine the participation of hepcidin in liver function. Moreover, there was a significant inverse correlation between Child-Pugh score as an indicator of severity of the liver disease and ascitic fluid hepcidin. This correlation may be caused by high level of serum ferritin as an indicator of iron overload in our HCV positive patients. Hepatic iron overload is even more common among patients with end-stage liver disease due to hepatitis $\mathrm{C}^{(33)}$. In contrast, Fujita et al. ${ }^{(27)}$ reported that serum albumin level was not correlated with hepcidin level and serum bilirubin was positively correlated with hepcidin.

Hepcidin regulates serum iron levels during inflammation, infection and possibly also in cancer. Under these conditions iron is shifted from circulation into cellular stores in hepatocytes and macrophages, making it less available for invading microorganisms and tumor cells ${ }^{(15)}$. Therefore, the role of hepcidin in human cancer deserves to be studied, since there have been only few reports in this context $^{(18,19,34)}$. It is well known that HCC develops in more than $40 \%$ of patients with hemochromatosis ${ }^{(35)}$.
Furthermore, some studies have indicated that iron overload is a major risk factor for development of $\mathrm{HCC}^{(36)}$. Iron overload leads to the generation of ROS, which cause chronic inflammation in the liver ${ }^{(37)}$. It is noteworthy that iron overload has been found to facilitate oxidative stress, steatosis development and with triggering of hepatic stellate cells thus inducing liver fibrosis and hepatocarcinogenesis in a mouse model transgenic for $\mathrm{HCV}^{(38,39)}$. In our study, serum ferritin was significantly higher in $\mathrm{HCV}$ positive patients with $\mathrm{HCC}$ than healthy controls. Serum hepcidin of HCV positive patients with HCC was significantly lower than healthy controls. The results are in agreement with previous studies. Hepcidin transcription was found to be downregulated in hepatoma cell lines expressing HCV core and nonstructural proteins ${ }^{(40)}$. Moreover, some studies demonstrated that expression of hepcidin mRNA was suppressed universally in HCC, irrespective of the degree of tumor differentiation. Expression of hepcidin mRNA is constitutively suppressed in cancerous, but not in non-cancerous liver tissue of patients with HCC $(34,41)$. Therefore, suppression of hepcidin hormone by hepatitis $\mathrm{C}$ virus is likely to be an important factor of liver iron accumulation in this condition (28). Iron is an essential nutrient for cell growth and particularly required by cancer cells to proliferate ${ }^{(42)}$. Therefore, the down-regulation of hepcidin may stimulate tumor progression in chronic $\mathrm{HCV}$ infection patients. This finding suggests that, hepcidin may play a role in defending the body against $\mathrm{HCC}$ development.

Although the mechanism responsible for suppression of hepcidin mRNA expression in HCC remains unclear, suppression of hepcidin transcription contradicts the previously proposed scheme for iron homeostasis in cancer cells, because cancer cells must retain iron in order to proliferate. However, suppression of hepcidin is rational because duodenal enterocytes transfer iron to plasma, resulting in an increase of total body iron content. One explanation was provided by Weizer-Stern et al. ${ }^{(43)}$ who reported that activation of the tumor suppressor gene p53 stimulates the expression of hepcidin. The promoter region of the hepcidin gene (HAMP) contains a putative p53 response element. Inactivation or mutation of the p53 gene has been detected in various types of human cancer ${ }^{(44)}$, including HCC ${ }^{(45)}$. Suppression of hepcidin expression may be linked to the altered expression and function of $\mathrm{p} 53$.

\section{Conclusion}

Low levels of hepcidin for the degree of iron burden may be involved in the pathophysiologic mechanism of increased iron overload in patients with chronic hepatitis $\mathrm{C}$ with and without HCC. Therefore, suppression of hepcidin by $\mathrm{HCV}$ is likely an important factor in liver iron accumulation in this condition. Iron overload has a potential negative effect in $\mathrm{CHC}$ in prognosis and development of HCC. The precise mechanism responsible for the suppression of hepcidin in HCC should be 
investigated further, focusing on its role in the development and maintenance of this cancer. Supplementation of hepcidin may be beneficial for these conditions.

Moreover, there is a positive relationship between hepcidin levels and synthetic liver function suggesting that a uniform suppression of hepcidin may be linked to disease progression and development of HCC. Further analysis is still required to evaluate its usefulness as a marker for early detection of HCC by serial measurement of hepcidin in blood and ascitic fluid.

\section{References}

[1] Lavanchy D. The global burden of hepatitis C. Liver Int 2009; 29: 74-81.

[2] Gomaa A I, Khan S A, Toledano M B, Taylor-Robinson S D. Hepatocellular carcinoma: Epidemiology, risk factors and pathogenesis. World J Gastroenterol 2008; 14(27): 4300-8.

[3] Ismail AM, Ziada HN, Sheashaa HA, Shehab El-Din AB. Decline of viral hepatitis prevalence among asymptomatic Egyptian blood donors: a glimmer of hope. Eur J Intern Med 2009;20(5):490-3.

[4] Lehman EM, Wilson ML. Epidemiology of hepatitis viruses among hepatocellular carcinoma cases and healthy people in Egypt: a systematic review and meta-analysis. Int J Cancer 2009;124(3):690-7.

[5] Park CH, Valore EV, Waring AJ, Ganz T. Hepcidin, a urinary antimicrobial peptide synthesized in the liver. J Biol Chem 2001; 276: 7806-10.

[6] Nemeth E, Tuttle MS, Powelson J, Vaughn MB, Donovan A, Ward DM, Ganz T, Kaplan J. Hepcidin regulates cellular iron efflux by binding to ferroportin and inducing its internalization. Science 2004; 306: 2090-3.

[7] Ganz T, Nemeth E. Iron Imports IV: Hepcidin and regulation of body iron metabolism. Am J Physiol Gastrointestinal Liver Physiol 2006; 290 (2): G199-G203.

[8] Kuston MD, Oukka M, Koss LM, Aydemir F, WesslingResnick M. Iron release from macrophages after erythrophagocytosis is up-regulated by ferroportin 1 over expression and down-regulated by hepcidin. Proc Natl Acad Sci USA 2005; 102: 1324-8.

[9] Pietrangelo A, Trautwein C. Mechanism of disease: The role of hepcidin in iron homeostasis-implications for hemochromatosis and other disorders. Nat Clin Prac Gastroenterol Hepatol 2004; 1: 39-45.

[10] Kemna EH, Tjalsma H, Willems HL, Swinkels DW. Hepcidin: from discovery to differential diagnosis. Haematologica 2008; 93: 90-7.

[11] Arnold J, Sangwaiya A, Bhatkal B, Geoghegan F, Busbridge M. Hepcidin and inflammatory bowel disease: dual role in host defence and iron homoeostasis. Eur J Gastroenterol Hepatol 2009; 21: 425-9.

[12] Arnold J, Sangwaiya A, Manglam V, Geoghegan F, Thursz M, Busbridge M. Presence of hepcidin-25 in biological fluids: Bile, ascitic and pleural fluids. World J Gastroenterol 2010; 16(17): 2129-33.
[13] Shike H, Lauth X, Westerman ME, Ostland VE, Carlberg JM, Van Olst JC, Shimizu C, Bulet P, Burns JC. Bass hepcidin is a novel antimicrobial peptide induced by bacterial challenge. Eur J Biochem 2002; 269: 2232-7.

[14] Nemeth E, Ganz T. Regulation of iron metabolism by hepcidin. Annu Rev Nutr 2006; 26: 323-42.

[15] Vyoral D, Petrák J. Hepcidin: a direct link between iron metabolism and immunity. Int $\mathrm{J}$ Biochem Cell Biol 2005;37(9):1768-73.

[16] Gattoni A, Parlato A, Vangieri B, Bresciani M, Derna R, Baldassarre R. Role of hemochromatosis genes in chronic hepatitis C. Clin Ther 2006;157:61-8.

[17] Nagashima M, Kudo M, Chung H, Ishikawa E, Hagiwara S, Nakatani T, et al. Regulatory failure of serum prohepcidin levels in patients with hepatitis C. Hepatol Res 2006;36:288-93.

[18] Ward DG, Roberts K, Brookes MJ, Joy H, Martin A, Ismail $\mathrm{T}$, Spychal R, Iqbal T, Tselepis C. Increased hepcidin expression in colorectal carcinogenesis. World $\mathrm{J}$ Gastroenterol 2008; 14: 1339-45.

[19] Kamai T, Tomosugi N, Abe H, Arai K, Yoshidal KI Increased serum hepcidin-25 level and increased tumor expression of hepcidin mRNA are associated with metastasis of renal cell carcinoma. BMC Cancer 2009; 9: 270.

[20] Corengia C, Galimberti S, Bovo G, Vergani A, Arosio C, Mariani $\mathrm{R}$, et al. Iron accumulation in chronic hepatitis $\mathrm{C}$ : relation of hepatic iron distribution, HFE genotype, and disease course. Am J Clin Pathol 2005; 124:846- 53.

[21] Krause A, Neitz S, Mägert HJ, Schulz A, Forssmann WG, Schulz-Knappe P, Adermann K. LEAP-1, a novel highly disulfide-bonded human peptide, exhibits antimicrobial activity. FEBS Lett 2000; 480: 147-50.

[22] Ganz T. Hepcidin: a key regulator of iron metabolism and mediator of anemia of inflammation. Blood 2003; 102: 7838 .

[23] Di Bisceglie AM, Axiotis CA, Hoofnagle JH, Bacon BR. Measurements of iron status in patients with chronic hepatitis. Gastroenterology 1992; 102:2108-13.

[24] Metwally MA, Zein CO, Zein NN. Clinical significance of hepatic iron deposition and serum iron values in patients with chronic hepatitis C infection. Am J Gastroenterol 2004; 99:286-91.

[25] Souza RM, Freitas LAR, Lyra AC, Moraes CF, Braga EL, Lyra LGC. Effect of iron overload on the severity of liver histologic alterations and on the response to interferon and ribavirin therapy of patients with hepatitis $\mathrm{C}$ infection. Braz J Med Biol Res 2006; 39:79-83.

[26] Nishina S, Hino K, Korenaga M, Vecchi C, Pietrangelo A, Mizukami $\mathrm{Y}$, et al. Hepatitis $\mathrm{C}$ virus induced reactive oxygen species raise hepatic iron level in mice by reducing hepcidin transcription. Gastroenterology 2008;134:226-38.

[27] Fujita N, Sugimoto R, Takeob M, Urawa N, Mifuji R, Tanaka H, Kobayashi Y, Iwasa M, Watanabe S, Adachi Y, KaitoM. Hepcidin Expression in the Liver: Relatively Low Level in Patients with Chronic Hepatitis C. Mol Med 2007; 13(1-2):97-104. 
[28] Girelli D, Pasino M, Goodnough JB, Nemeth E, Guido M, Castagna A, Busti F, Campostrini N, Martinelli N, Vantini I, Corrocher R, Tomas Ganz T, and Fattovich G. Reduced serum hepcidin levels in patients with chronic hepatitis C. J Hepatol 2009; 51(5): 845-52.

[29] Liu H, Trinh TL, Dong H, Keith R, Nelson D, Liu C. Iron Regulator Hepcidin Exhibits Antiviral Activity against Hepatitis C Virus. PLoS ONE 2012; 7(10): e46631.

[30] Aoki CA, Rossaro L, Ramsamooj R, Brandhagen D, Burritt MF, Bowlus CL. Liver hepcidin mRNA correlates with iron stores, but not inflammation, in patients with chronic hepatitis C. J Clin Gastroenterol 2005;39:71-4.

[31] Nicolas G, Chauvet C, Viatte L, Danan JL, Bigard X, Devaux I, et al. The gene encoding the iron regulatory peptide hepcidin is regulated by anemia, hypoxia, and inflammation. J Clin Invest 2002; 110: 1037-44.

[32] Napoli J, Bishop GA, McGuinness PH, et al. Progressive liver injury in chronic hepatitis $\mathrm{C}$ infection correlates with increased intrahepatic expression of Th1- associated cytokines. Hepatology 1996; 24: 759-65.

[33] Tung BY, Emond MJ, Bromer MP, Raaka SD, Cotler SJ, Kowdley KV. Hepatitis C, iron status, and disease severity: relationship with HFE mutations. Gastroenterology 2003; 124:318-26.

[34] Kijima H, Sawada T, Tomosugi N and Kubota K. Expression of hepcidin mRNA is uniformly suppressed in hepatocellular carcinoma. BMC Cancer 2008; 8:167.

[35] Fargion S, Mandelli C, Piperno A, Cecana B, Conte D, et al. Survival and prognostic factors in 212 Italian patients with genetic hemochromatosis. Hepatology 1992; 15: 655-9.

[36] Deugnier Y, Turlin B, Loréal O. Iron and neoplasia. J Hepatol 1998;28:21-5.
[37] Hentze MW, Muckenthaler MU, Andrews NC: Balancing acts: molecular control of mammalian iron metabolism. Cell 2004; 117:285-97.

[38] Furutani T, Hino K, Okuda M, Gondo T, Nishina S, Kitase A, et al. Hepatic iron overload induces hepatocellular carcinoma in transgenic mice expressing the hepatitis $\mathrm{C}$ virus polyprotein. Gastroenterology 2006;130:2087-98.

[39] Valenti L, Pulixi EA, Arosio P, Cremonesi L, Biasiotto G, Dongiovanni P, Maggioni M, Fargion S, Fracanzani AL. Relative contribution of iron genes, dysmetabolism and hepatitis $\mathrm{C}$ virus $(\mathrm{HCV})$ in the pathogenesis of altered iron regulation in HCV chronic hepatitis. Haematologica 2007; 92:1037-42.

[40] Miura K, Taura K, Kodama Y, Schnabl B, Brenner DA. Hepatitis C virus-induced oxidative stress suppresses hepcidin expression through increased histone deacetylase activity. Hepatology 2008;48:1420-9.

[41] Abd Elmonem E, Tharwa E, Farag M A, Fawzy A, El Shinnawy S F, Suliman S. Hepcidin mRNA Level as A Parameter of Disease Progression in Chronic Hepatitis C and Hepatocellular Carcinoma. Journal of the Egyptian Nat. Cancer Inst 2009; 21(4): 333-42.

[42] Le NT, Richardson DR. The role of iron in cell cycle progression and the proliferation of neoplastic cells. Biochim Biophys Acta 2002; 1603: 31-46.

[43] Weizer-Stern O, Adamsky K, Margalit O, Rechavi G, et al. Hepcidin, a key regulator of iron metabolism, is transcriptionally activated by p53. Br J Haematol 2007; 138: 253-62.

[44] Levine AJ, Momand J, Finlay CA. The p53 tumour suppressor gene. Nature 1991; 351: 453-6.

[45] Laurent-Puig P, Zuckman-Rossi J. Genetics of Hepatocellular tumors. Oncogene 2006; 25: 3778-86. 